\title{
JNPH
}

Volume 5 No. 2 (Desember 2017)

(C) The Author(s) 2017

\section{KEPERAWATAN PADA Tn.U DENGAN FILARIASIS DI DESA RENA PANJANG WILAYAH UPTD PUSKESMAS TUMBUAN KECAMATAN LUBUK SANDI KABUPATEN SELUMA KOTA BENGKULU}

\author{
NURSING IN Tn.U WITH FILARIASIS IN RENA PANJANG REGION AREA \\ AT UPTD TUMBUAN PUBLIC HEALTH CENTER LUBUK SANDI DISTRICT \\ SELUMA REGENCY BENGKULU CITY
}

\author{
SIPENTRI \\ UPTD PUSKESMAS TUMBUAN SELUMA \\ Email: sipentrilinhari@gmail.com
}

\begin{abstract}
ABSTRAK
Penularan filariasis terjadi apabila ada lima unsur utama yaitu sumber penular (manusia dan hewan sebagai reservoir), parasit (cacing), vektor (nyamuk) host (manusia yang rentan), lingkungan (fisik, biologik, ekonomi dan sosial budaya). Salah satu teori keperawatan yang dapat digunakan adalah teori King memahami model konsep dan teori keperawatan dengan menggunakan pendekatan system terbuka dalam hubungan interaksi yang konstan dengan lingkungan, sehingga King mengemukakan dalam model konsep interaksi. Tujuan penelitian untuk menerapkan aplikasi model konsep keperawatan Imogene King pada pasien Filariasis di Desa Rena Panjang Wilayah UPTD Puskesmas Tumbuan Kecamatan Lubuk Sandi Kabupaten Seluma Kota Bengkulu. Dalam penelitian ini penulis akan mengurai laporan kasus/asuhan keperawatan yang diberikan pada Tn. U dengan mengaplikasikan teori model Imogene King yang dilaksanakan selama 1 minggu pada tanggal 10-16 Mei 2017 dengan menggunakan metode proses keperawatan yang meliputi pengkajian, diagnosa keperawatan, perencanaan, implementasi dan evaluasi asuhan keperawatan ini. Hasil penelitian menurut King, melalui pengelolaan faktor-faktor stimulasi, pencetus tidak efektifnya perilaku diubah atau meningkatkan kemampuan individu untuk mengatasi masalah. Jadi stimulasi akan jatuh ke area yang dibangun oleh tingkat penyesuaian diri manusia dan perilaku adaptif akan terjadi. intervensi keperawatan berikutnya, mengevaluasi hasil akhir perilaku dan memodifikasi pendekatan keperawatan sesuai kebutuhan ini harus dicatat bahwa dalam model manusia dihormati sebagai individu yang berpartisipasi aktif dalam perawatan dirinya, tujuan disusun berdasarkan tujuan yang saling menguntungkan. Kepada pihak pelayanan kesehatan diharapkan dapat menerapkan aplikasi keperawatan pada pasien dengan aplikasi yang ada seperti dengan menggunakan aplikasi teori Imogene King, ataupun aplikasi teori lainnya yang sesuai dengan keadaan pasien dan teori yang ada sehingga didapatkan hasil perawatan yang optimal.
\end{abstract}

Kata Kunci: filariasis, imogene king

\begin{abstract}
Transmission of filariasis occurs when there are five main elements: the source of the transmitter, the parasite, the vector, the host, the environment (physical, biological, economic and socio-cultural). One of the theories of nursing that can be used is King's theory of
\end{abstract}


understanding the concept model and the theory of nursing by using an open system approach in a constant interaction with the environment, so King put forward in the concept of interaction model. Purpose of research to Implement Applying Imogene King Implant Concept Model in Filariasis patient in Desa Rena Panjang Area UPTD Tumbuan Health Center Kecamatan Lubuk Sandi Seluma District Bengkulu City. In this study the authors will parse the case report / nursing care given to Mr. Tn. U by applying Imogene King model theory which was implemented for 1 week on May 10-16, 2017 using nursing process method which includes assessment, nursing diagnosis, planning, implementation and evaluation of this nursing care. Research results According to King, through stimulation factors, the initiator of ineffective behavior changed or improve the ability of individuals to solve problems. So the stimulation will fall into an area built by the level of human self-adjustment and adaptive behavior will occur. The following nursing interventions, evaluating the behavioral outcome and modifying the nursing approach according to this need should be noted that in the human model is respected as an individual who actively participates in his or her care, goals are organized on the basis of mutually beneficial purposes. To the health service is expected to apply nursing applications in patients with existing applications such as using Imogene King theory application, or other theoretical applications in accordance with the patient's situation and the existing theories to obtain optimal care results.

\section{Keywords: filariasis, imogene king}

\section{PENDAHULUAN}

Kesehatan adalah keadaan sejahtera dari badan, jiwa, dan sosial yang memungkinkan setiap orang hidup produktif secara sosial dan ekonomis. Pembangunan kesehatan bertujuan untuk meningkatkan kesadaran, kemauan dan kemampuan hidup sehat bagi setiap orang agar terwujud derajat kesehatan masyarakat yang setinggi-tingginya. Kegiatan untuk meningkatkan kesehatan (promotif), mencegah penyakit (preventif), terapi (kuratif) maupun pemulihan kesehatan (rehabilitatif) adalah upaya kesehatan masyarakat (Depkes RI, 2010).

Filariasis (penyakit kaki gajah) adalah penyakit menular menahun yang disebabkan oleh cacing filaria dan ditularkan oleh nyamuk Mansonia, Anopheles, Culex, Armigeres. Cacing tersebut hidup di saluran dan kelenjar getah bening dengan manifestasi klinik akut berupa demam berulang, peradangan saluran kelenjar getah bening. Pada stadium lanjut dapat menimbulkan cacat menetap berupa pembesaran kaki, lengan, payudara dan alat kelamin (Chin, 2013). Tiga spesies cacing filaria penyebab filariasis limfatik adalah Wuchereria bancrofti,Brugia malayi dan Brugia timori (Depkes RI, 2010).

Sekarang ini, lebih dari 1,4 milyar orang di 73 negara beresiko terinfeksi cacing filariasis. Kira-kira $65 \%$ yang terinfeksi berada di wilayah Asia Tenggara, 30\% di wilayah Afrika, dan sisanya berada di daerah tropis. Filariasis limfatik menyebabkan lebih dari 25 juta laki-laki dengan gangguan genital dan lebih dari 15 juta orang dengan limfoedema (WHO, 2013). Filariasis di Indonesia pertama kali dilaporkan oleh Haga dan Van Eeckepada tahun 1889 di Jakarta yaitu ditemukan penderita filariasis skrotum. Pada saat itu pula Jakarta salah satu ibu kota terbesar yang memiliki penderita filariasis terbesar di Indonesia. Diketahui endemik filariasis limfatik yang disebabkan oleh B.Malayi ( Depkes RI, 2005).

Penyakit ini merupakan salah satu masalah kesehatan masyarakat yang serius di Indonesia. Hampir seluruh wilayah Indonesia adalah daerah endemis filariasis, terutama wilayah Indonesia Timur yang memiliki prevalensi lebih tinggi. Hasil laporan kasus klinis kronis filariasis dari kabupaten/kota yang ditindaklanjuti dengan survey endemisitas filariasis, sampai dengan tahun 2013 terdapat 337 kabupaten/kota endemis dan 135 kabupaten/kota non endemis. Dari tahun 2005 hingga 2012 terdapat peningkatan yang sangat tinggi. Pada tahun 2005 jumlah 
kasus yang dilaporkan sebanyak 6720 kasus dan pada tahun 2012 meningkat menjadi 11.699 kasus. Diperkirakan sampai tahun 2013 penduduk berisiko tertular filariasis lebih dari 125 juta orang yang tersebar di 337 kabupaten/kota endemis filariasis dengan 11.914 kasus kronis yang dilaporkan dan diestimasikan prevalensi mikrofilaria 19\%, kurang lebih penyakit ini akan mengenai 40 juta penduduk ( Depkes RI, 2010). Penyakit ini memberikan dampak sosial budaya yang cukup besar, dampak ekonomi serta mental secara psikologis, sehingga tidak dapat bekerja secara optimal dan hidupnya selalu tergantung pada orang lain (WHO, 2013).

Provinsi Sumatera merupakan salah satu daerah endemis filariasis di Indonesia. Berdasarkan laporan tahunan filariasis provinsi Sumatera tahun 2013, di Sumatera jumlah kasus filariasis sebanyak 238 orang yang tersebar di 19 Kabupaten/ Kota (Dinkes Sumbar,2013). Provinsi Bengkulu bukan salah satu 5 provinsi daerah endemis filariasis namun merupakan provinsi yang banyak ditemukan kasus baru filariasis di Sumatera. Berdasarkan laporan diketahui bahwa jumlah kasus filariasis yang ditemukan meningkat dari tahun ke tahun. Pada tahun 2014 ditemukan 56 kasus dan tahun 2015 ditemukan 97 kasus lagi sedangkan pada tahun 2016 meningkat menjadi 109 kasus filariasis (Dinkes, 2016).

Penularan filariasis terjadi apabila ada lima unsur utama yaitu sumber penular (manusia dan hewan sebagai reservoir), parasit (cacing), vektor (nyamuk), host (manusia yang rentan), lingkungan (fisik, biologik, ekonomi dan sosial budaya) (Nursalam, 2015). Banyak faktor risiko yang mampu memicu timbulnya kejadian filariasis. Beberapa diantaranya adalah jenis kelamin, usia, pekerjaan, faktor lingkungan, perilaku. Pada umumnya kelompok umur dewasa muda dan laki-laki lebih banyak yang terkena infeksi karena laki-laki lebih besar kesempatan untuk terpapar dengan infeksi (exposure) dari pada perempuan (Sutanto, 2011).

Penelitian yang dilakukan oleh
Kadarusman di Jambi dan Njenga, S.M. et al. di Kenya ditemui bahwa laki-laki lebih berisiko dibandingkan perempuan dalam penyakit ini. Hal ini kemungkinan terkait dengan aktifitas yang dilakukan. Banyak lakilaki yang memiliki aktifitas di luar rumah pada malam hari, misal ronda. Selain itu, sebagaipencari nafkah utama bagi keluarga, laki-laki memiliki mobilitas yang lebih tinggi dibandingkan perempuan. Kemungkinan kontak dengan vektor akan menjadi lebih besar juga dibandingkan perempuan (Kadarusman, 2014 : Njenga SM, 2009).

Faktor pekerjaan seperti nelayan yang mempunyai kebiasaan berlayar padamalam hari dapat terpapar oleh nyamuk penular yang berkembangbiak di pinggir pantai, hal ini berkaitan dengan kebiasaan menggigit nyamuk penular pada malam hari (Sutanto, 2011). Menurut hasil penelitian Nasrin(2008) di kabupaten Bangka Barat orang yang memiliki jenis pekerjaan berisiko akan berpeluang terkena penyakit filariasis sebesar 4,4 kali dibandingkan dengan orang yang memiliki pekerjaan tidak berisiko (Nasrin, 2008).

Faktor lingkungan terkait dengan tempat perkembangbiakan nyamuk sebagai vektor dari penyakit ini. Filariasis bancrofti ada 2 macam yaitu filariasis bancrofti perkotaan dengan vektor utamanya Culex fatigans yang hidup di dalam rumah, tempat perindukannya pada air kotor sekitar rumah dan filariasis bancrofti pedesaan vektornya nyamuk Aedes, Anopheles dan Mansoni. B. malayi dan B.timori hanya terdapat di pedesaan, karena vektornya tidak dapat berkembang biak di perkotaan. B. timori biasanya terdapat didaerah persawahan sesuai dengan tempat perindukan vektornya $A n$. barbirostris, $B$. malayi yang terdapat pada manusia dan hewan biasanya terdapat dipinggir pantai atau aliran sungai, dengan rawa-rawa. Menurut hasil penelitian Sarungu di Distrik Windesi Kabupaten Kepulauan Yapen Provinsi Papua bahwa kondisi lingkungan fisik dan kimia mendukung perkembangan nyamuk vektor filariasis serta keberadaan keberadaan genangan air yang mengandung jentik 
nyamuk meningkatkan risiko penularan filariasis sebesar 6,00 kali. (Natadisastra, 2009; Sarungu Y, 2012; Sutanto, 2009; Zainul, 2014)

Faktor risiko selanjutnya adalah kebiasaan keluar rumah pada malam hari dan kebiasaan tidak menggunakan kelambu saat tidur. Selain itu, pengetahuan mengenai filariasis yang akan meningkatkan kesadaran individu serta terjadinya resistensi vektor filariasis terhadap insektisida masuk ke dalam faktor risiko yang harus diperhatikan (Dinkes Padang Pariaman, 2012; Juriastuti P, 2010). pencegahan penyakit dengan kejadian filariasis. Hal ini berarti orang yang tidak melakukan tindakan pencegahan penyakit lebih besar peluangnya untuk terkena penyakit filariasis (Rosmadeli, 2008). Teori adaptasi King menitikberatkan pendekatan pada tiga hal meliputi stimulus fokal yaitu stimulus atau rangsangan yang berasal dari dalam individu maupun dari luar individu dan harus dihadapi secara langsung pada saat itu juga. Stimulus kontekstual adalah semua stimulus yang berpengaruh terhadap stimulus fokal berasal dari lingkungan sekitar, sedangkan stimulus residual merupakan faktor yang berasal dari lingkungan sekitar yang dapat berpengaruh secara tidak langsung pada individu (Tomey \& Alligood, 2010).

Menurut hasil penelitian Nasrin(2008) di Kabupaten Bangka Barat tentang faktorfaktor lingkungan dan perilaku yang berhubungan dengan kejadian filariasis ditemukan hubungan yang bermakna antara jenis pekerjaan, tingkat penghasilan dan pengetahuan terhadap kejadian filariasis (Nasrin, 2008). Penelitian Rosmadeli (2008) menyimpulkan terdapat hubungan perilaku Survey awal penelitian dilakukan di UPTD Puskesmas Tumbuan Kabupaten Seluma Kecamatan Sukaraja Kota Bengkulu dari data pencatatan sejumlah kasus dengan filariasis sebanyak 5 kasus dalam 3 tahun terakhir ini. Dari jumlah tersebut tercatat data tahun 2014 jumlah 1 kasus filariasis dan pada tahun 2015 tercatat 1 kasus sedangkan pada tahun 2016 meningkat tajam 3 kasus filariasis yang menjalani terapi lebih lanjut (UPTD
Puskesmas Tumbuan, 2016)

\section{TUJUAN PENELITIAN}

Tujuan dari penelitian ini untuk menerapkan aplikasi teori model Imogene King dapat di aplikasikan dengan baik dalam pelayanan kesehatan atau asuhan keperawatan dengan Filariasis pada masyarakat wilayah UPTD Puskesmas Tumbuan Kabupaten Seluma Kota Bengkulu.

\section{METODE PENELITIAN}

Jenis studi kasus ini adalah studi kasus Filariasis dengan aplikasi teori Imogene King dengan menggunakan metode deskriptif yaitu suatu metode yang dilakukan dengan tujuan utama untuk membuat gambaran atau deskripsi tentang suatu keadaan secara obyektif dan memusatkan perhatian pada objek tertentu (Notoatmojo, 2010).

\section{HASIL PENELITIAN}

Aplikasi teori Imogene King dalam pemberian asuhan keperawatan pada $\mathrm{Tn}$. U dengan Filariasis. Dalam Bab ini, penulis akan membahas meliputi segi pengkajian, diagnosa, perencanaan keperawatan, implementasi keperawatan, dan evaluasi keperawatan mengenai kasus yang penulis angkat

\subsection{Tahap Pengkajian}

Pengkajian adalah tahap awal untuk melakukan sesuatu asuhan keperawatan yang berguna untuk mengumpulkan data sebagai dasar untuk mengetahui kebutuhan klien sehingga dapat menentukan asuhan keperawatan yang akan dilakukan. Dalam pengumpulan data penulis menggunakan metode wawancara atau tanya jawab dengan klien serta observasi dengan menggunakan pemeriksaan fisik. Dalam pengkajian keperawatan ini difokuskan pada teori imogene king.

Berdasarkan hasil pengkajian didapatkan 
pasien dengan keluhan utamanya Tn. U mengatakan demam berulang-ulang selama 4 hari, demam hilang bila istirahat dan demam akan muncul lagi ketika bekerja berat, kaki terasa sakit dan membengkak bila sering digerakkan. Pengamatan yang dilakukan pada Tn. U : Klien mengatakan merasakan nyeri, panas, dan sakit yang menjalar dari pangkal kaki ke arah ujung kaki, Nyeri terasa berulang-ulang, dengan skala nyeri 7 dengan durasi kurang lebih 5 menit. Demam berulang-ulang selama 4 hari, demam hilang bila istirahat dan demam akan muncul lagi ketika bekerja berat, akral teraba dingin, badan teraba hangat, mukosa bibir klien tampak kering. Pada pengkajian Tn. U ditemukan data yang paling menonjol dari item pengkajian antara lain yaitu : nyeri, peningkatan suhu tubuh, gangguan mobilisasi b/d pembengkakan pada tungkai kaki, resti penularan penyakit.

Menurut pengembangan teori imogene king pengkajian dilakukan pada tahap penggalian informasi dari pasien dengan tetap menjaga komunikasi dengan baik dan mampu menyesuaikan dengan kondisi sosial dan budaya yaitu aksi merupakan proses awal hubungan dua individu dalam perilaku memahami dan mengenal kondisi yang ada dalam keperawatan dengan digambarkan hubungan perawat dengan klien untuk melakukan kontrak dan tujuan yang diharapkan, reaksi suatu bentuk tindakan yang terjadi akibat adanya aksi daan merupakan respon dari individu, interaksi suatu bentuk kerja sama yang saling mempengaruhi antara perawat dan klien yang terwujud dalam komunikasi, transaksi kondisi dimana antara perawat dan klien menjadi suatu persetujuan dalam rencana tindakan perawatan yang akan dilakukan pola kontrol dan pengaturan termasuk respon strees dan sistem reproduksi, pengkajian konsep diri, pengkajian fungsi peran (sosial) dan pengkajian interdependensi.

\subsection{Diagnosa Keperawatan}

Diagnosa keperawatan memberikan dasar untuk pemilihan intervensi keperawatan, untuk mencapai hasil yang merupakan tanggung jawab perawat. pada asuhan keperawatan Tn. U dengan filariasis ditemukan diagnosa keperawatan meliputi : Nyeri berhubungan dengan Adanya Peradangan pada kelenjar limfe, peningkatan suhu tubuh berhubungan dengan Adanya Inflamasi pada kelenjar getah bening, gangguan mobilitas fisik berhubungan dengan Adanya pembengkakan pada kelenjar limfe di daerah tungkai (inguinal).

King mendefinisikan untuk menyusun diagnosa keperawatan, menggunakan tipologi diagnosa yang dikembangkan oleh King dan berhubungan dengan 4 model adektif. Jika peningkatan adaptasi dalam tiap cara menyesuikan diri : fungsi fisologi, konsep diri, fungsi peran dan interdependen. Harapan dalam tahap ini setelah dilakukan pengkajian perawat dapat memberikan kesimpulan awal dan tetap menjaga komunikasi yang baik kepada klien dan pasien serta keluarga. Tujuan perawatan diraih ketika stimulasi fokal berada didalam suatu area tingkatan adaptasi manusia, dan ketika stimulasi fokal tersebut tidak ada dalam area, manusia dapat membuat suatu penyesuaian diri atau respon efektif.

\subsection{Intervensi keperawatan}

Dalam penyusunan perencanaan keperawatan, penulis melakukan sesuai dengan diagnosa yang telah di perioritaskan yaitu dengan kompenen tujuan, kriteria dan rencana keperawatan. Dalam menentukan intervensi keperawatan pada pasien penulis menyusun sesuai dengan apa yang dibutuhkan pasien, dan kapasitas intelektual pasien. Pada penetapan tujuan dan rencana tindakan perawat akan memfasilitasi Tn. U dalam melakukan penanganan pada masalah filariasisnya, meliputi masalah gangguan istrirahat tidur dan resiko tinggi terjadinya infeksi pada filariasis yang dialami Tn. U.

Menurut King intervensi keperawatan adalah perencanaan dengan tujuan merubah atau memanipulasi stimulus fokus, 
konteksual, dan residual. Pelaksanaan juga ditujukan kepada kemampuan klien dalam koping secara luas, supaya stimulasi secara keseluruhan dapat tejadi pada klien, sehingga total stimuli berkurang dan kemampuan adaptasi meningkat. Tujuan intervensi keperawatan adalah pencapaian kondisi yang optimal, dengan menggunakan koping yang konstruktif. Tujuan jangka panjang harus dapat menggambarkan penyelesaian masalah adaptif dan ketersedian energi untuk memenuhi kebutuhan tersebut (mempertahankan, pertumbuhan, reproduksi). Tujuan jangka pendek mengidentifikasi harapan perilaku klien setelah manipulasi stimulus fokal, konstekstual dan residual.

\section{PEMBAHASAN}

\section{Implementasi Keperawatan}

Pada pelaksanaan tindakan keperawatan pada klien seluruh rencana tindakan dapat diaplikasikan dengan baik dan tidak ada masalah yang berarti. Karena banyak hal yang mendukung dalam pelaksanaan asuhan keperawatan ini. Adapun faktor yang mendukung implementasi: adanya keinginan pasien untuk sembuh sehingga pasien menerima saran dan anjuran keperawatan, adanya keinginan pasien dan untuk mengetahui penanganan penyakitnya. Semua masalah yang ada penulis dapat melaksanakannya dan dari tindakan yang telah direncanakan dan diimplementasikan atas persetujuan pasien serta berdasarkan standar praktek keperawatan. Implementasi keperawatan direncanakan dengan tujuan merubah atau memanipulasi fokal, konstektual, dan residula stimulasi dan juga memperluas kemampuan koping seseorang pada zona adaptasi sehingga total stimuli berkurang dan kemampuan adaptasi meningkat (Asmadi, 2008).

King (1981) menggambarkan sebagai disiplin ilmu dan praktek, sebagai ilmu keperawatan mengobservasi, mengklasifikasi dan menghubungkan proses yang secara positif berpengaruh pada statatus kesehatan yang meliputi: Keperawatan berusaha untuk mengintegrasikan, sistem pribadi interpersonal dan sosial yang mempengaruhi kesehatan pasien dan merupakan model penting untuk perawatan kesehatan di masa sekarang dan di luar (Whelton, 1999). Model konseptual King menggaris bawahi pentingnya interaksi perawat-pasien yang menganggap antarmuka ini sebagai suatu sistem terbuka yang bersentuhan terus dengan berbagai faktor lingkungan ( George, 2002). teori sistem dan teori pencapaian tujuan king langsung bergabung dengan sistem klasifikasi seperti hasil keperawatan, intervensi, dan diagnosis, menunjukkan bahwa teori pencapaian tujuan sangat penting untuk berbasis bukti praktek keperawatan (Malinski, 2002).

Keterampilan komunikasi yang buruk juga mempengaruhi penetapan tujuan dan pencapaian tujuan (Williams, 2001). keharusan bagi perawat dalam serangkaian komunikasi dengan pasien maupun dalam penyuluhan kesehatan dimasyarakat. Empat keharusan tersebut yakni:pengetahuan, ketulusan, semangat, praktek (Karioso). Dalam tahap ini yaitu pengaplikasiannya tetap berkomunikasi dan berkerja sama dalam penanganan terhadap pasien.

\section{Evaluasi Keperawatan}

Evaluasi keperawatan adalah proses keperawatan mengukur respon klien terhadap tindakan keperawatan dan kemajuan klien ke arah pencapaian tujuan (potter dan perry 2006). Dari 2 diagnosa yang penulis temukan, semua sesuai dengan masalah yang dialami pasien Tn. U pada saat penulis melakukan studi kasus kepada Tn. U semua intervensi sudah mencapai kriteria hasil. Pasien mampu melakukan hidup sehat dan melakukan pencegahan filariasis, pasien mampu berperilaku yang baik dalam penanganan yang baik terhadap penyakit yang dideritanya dan tidak ada tanda infeksi serta kebutuhan tidur pasien terpenuhi. Menurut King penilaian terakhir dari proses keperawatan berdasarkan tujuan keperawatan yang 
ditetapkan. Penetapan keberhasilan suatu asuhan keperawatan didasarkan pada perubahan perilaku dari kriteria hasil yang ditetapkan yaitu terjadinya adaptasi pada individu (Asmadi, 2008).

\section{Keefektifan aplikasi teori dalam penyelesaian masalah yang diangkat}

Keefektifan aplikasi teori King pada pelaksanaan asuhan keperawatan pada pasien filariasis yaitu dapat meningkatkan perilaku yang baik pada penderita filariasis dalam melakukan upaya penanganan dan upaya pencegahan terhadap terjadinya filariasis. Sehingga dapat disimpulkan bahwa dari semua tindakan perawatan kepada pasien dengan menggunakan aplikasi teori King dapat meningkatkan kesehatan pasien secara optimal baik jangka panjang maupun jangka pendek.

\section{Keunggulan aplikasi teori dalam menyelesaikan masalah yang diangkat}

Keunggulan King dalam pelaksanaan kasus ini adalah dimana pada pengkajian mencakup semua pada askep fisiologis maupun aspek psikologis dan faktor sistem pendukung terjadinya masalah pada pasien. Selain itu juga pada hasil yang didapat pada asuhan keperawatan ini sangat efektif sebagai upaya meningkatkan perilaku pasien dalam melakukan penanganan pada penyakitnya dan upaya jangka panjang dalam mencegah penyakit tersebut berulang. Menurut King, melalui pengelolahan faktor-faktor stimulasi, pencetus tidak efektifnya perilaku diubah atau meningkatkan kemampuan individu untuk mengatasi masalah. Jadi stimulasi akan jatuh ke area yang dibangun oleh tingkat penyesuaian diri manusia dan perilaku adaptif akan terjadi. Intervensi keperawatan berikutnya, mengevaluasi hasil akhir perilaku dan memodifikasi pendekatan keperawatan sesuai kebutuhan ini harus dicatat bahwa dalam model manusia dihormati sebagai individu yang berpartisipasi aktif dalam perawatan dirinya, tujuan disusun berdasarkan tujuan yang saling menguntungkan.

\section{Kelemahan aplikasi teori dalam meyelesaikan masalah yang diangkat}

Kelemahan dari model adaptasi King ini adalah terletak pada sasarannya. Model adaptasi King ini hanya berfokus pada proses adaptasi pasien dan bagaimana pemecahan masalah pasien dengan menggunakan proses keperawatan dan tidak menjelaskan bagaimana sikap dan perilaku cara merawat (caring) pada pasien. Sehingga seorang perawat yang tidak mempunyai perilaku caring ini akan menjadikan sterssor bagi para pasien.

\section{KESIMPULAN}

Intervensi dan implementasi yang ditegakkan oleh penulis sudah sesuai dengan teori Imogene King sesuai diagnosa yang ditegakkan, implementasi dilakukan sesuai dengan rencana keperawatan yang disusun, disertai respon hasil dari pasien, tahap evaluasi dari diagnosa keperawatan yang penulis implementasikan selama 3 hari berhasil dilakukan, teori Model Orem efektif di aplikasikan pada pasien dengan kasus Filariasis.

\section{SARAN}

Kepada pihak pelayanan kesehatan diharapkan dapat menerapkan aplikasi keperawatan pada pasien dengan aplikasi yang ada seperti dengan menggunakan aplikasi teori Imogene King, ataupun aplikasi teori lainnya yang sesuai dengan keadaan pasien dan teori yang ada sehingga didapatkan hasil perawatan yang optimal.

\section{DAFTAR PUSTAKA}

Asmadi. 2008. Konsep Dasar Keperawatan. Jakarta: Buku Kedokteran EGC

Christensen, J.P. 2009. Dermatologi Praktis, Jakarta:Hipokrates 
Depkes RI. 2010. Rencana Straegis Kementrian Kesehatan, Jakarta

Dinkes Sumber. 2013. Jurnal Filariasis. Universiti

Dinkes . 2016. Data Penyakit Filariasis/Kaki Gajah, Bengkulu

Dinkes Padang Pariaman. 2012. Data Penyakit Filariasis, Padang

Djuanda. 2016. Ilmu Penyakit Menular dan Kelainan, Jakarta : FKUI

Ermer, P, Noble . 2010. Prosedur Penelitian Pendekatan Praktis, Jakarta: Rineka

Fawceet. 2005. Penyakit Dalam, Jakarta: Salemba

George. 2002. Deteksi Dini Penyakit Menular, Yayasan Bina Pustaka.

Harun, Riyanto. 2010. Rencana Asuhan Keperawatan, Jakarta : EGC

Imogene King. 1977-1981. Aplikasi Model Imogene King

Juriastuti. 2010. Patofisiologi Konsep Klinis Proses Penyakit, Jakarta : EGC

Kadarusman. 2014. Anatomi Fisiologi Asuhan Keperawatan, Edisi III. Jakarta : EGC

Meleis. 2006. Konsep Keperawatan, Jakarta : YBP

Murwani. 2009. Buku Ajar Keperawatan Medical Bedah, Jakarta : EGC

Natadisastra. 2009. Kesehatan Lingkungan, Jakarta : IDAL

Nursalam. 2015. Manajemen Keperawatan Aplikasi dalam Praktek Keperawatan Profesional, Salemba Medika: Jakarta

P2M \& PLP. 2009. 5 Langka Mengenali Gejala Filariasis, Buku Saku, Jakarta

Rosmadeli. 2008. Metode penelitian., Bandung:CV Alfabeth

Sarungu, Y. 2012. Buku Ajar Penyakit Dalam, jakarta : FKUL

Sutanto. 2009-2011. Filariasis, Jakarta:IDI

T. Pohan Herdiman. 2009. Pelayanan Kesehatan Keperawatan, Jakarta : JNBKK-POGI

UPTD Puskesmas Tumbuan. 2016. Profil Data Penyakit Filariasis, Bengkulu

Potter dan perry.2006. Buku ajar Fundamental Keperawatan Volume 2. Edisi 4, Jakarta : EGC
Zainal. 2014. Prosedur Penelitian Suatu Pendekatan Praktik, Jakarta : PT. Asdi Mahasatya 